\title{
PERFORMANCE OF RATOON RICE UNDER DIFFERENT STUBBLE CUTTINGS AND FERTILIZER MANAGEMENT
}

\author{
BAYANI J. DEJAÑO \\ Instructor III, Negros State College of Agriculture \\ Kabankalan City, Negros Occidental
}

and

\section{REYNALDO R. JAVIER}

Professor, Department of Agronomy and Soil Science

Leyte State University, Visca, Baybay, Leyte

\section{ABSTRACT}

Stubble cutting heights significantly affected the agronomic characteristics as well as the yield and yield components of ratoon rice. Similarly, fertilizer treatment mostly influenced the agronomic and yield and yield components of ratoon rice. Plants applied with basal or foliar or a combination of two were havested late, grew taller, had wider leaf area, higher straw yield, more tillers, longer and heavier panicles, more yield and harvest indices. Cost and return of main crop + ratoon crop using the different stubble cutting heights and fertilizer treatments were economically profitable. Results showed that basal application of fertilizer at a rate of $60-30-30 \mathrm{~kg} \mathrm{~N}, \mathrm{P}_{2} \mathrm{O}_{5}$ and $\mathrm{K}_{2} \mathrm{O}$ obtained the highest net return of $\$ 19,868.56$

KEY WORDS: Rice. Ratooning. Stubble cuttings. Fertilizer management. 


\section{INTRODUCTION}

Rice (Oryza sativa L.) is one of the most important foods throughout the world (Hardy, 1998). Globally, rice ranks second to wheat in area harvested but in terms of importance as a food crop, rice provides more calories per hectare than any other cereal crops.

With the increasing population in the country, Filipinos need to further increase rice production to meet the demand with less input cost every cropping period (Hardy, 1998). Ratooning may be one of the solutions to this problem. This could be a practical way to increase rice production per unit area and time because a ratoon crop has a shorter growth duration than a main crop.

Rice ratooning is not a new practice with farmers (De Datta and Bernaso, 1988). Its usefulness has been studied in many countries. It is only in Texas, USA where it is practiced on commercial scale on $50 \%$ of the rice area. However, problems like fertilizer management are important aspects to consider. In modern agriculture, cultural management such as fertilizer application especially during ratooning affects the production of ratooned rice. At present, no study has yet been conducted in Eastern Visayas regarding the proper management of fertilizer and appropriate cutting height of rice used for ratoon crop.

\section{METHODOLOGY}

The experiment was conducted in two successive cropping seasons, wet season and dry season, with an interval of one month turnaround time between each cropping period. 
An area of $1,119 \mathrm{~m}^{2}$ at the experimental station of the Department of Agronomy and Soil Science with clay loam soil was plowed and harrowed three times at 10 days interval. Rice variety, IR60 noted by farmers for its high ratooning ability was used, in the experiment. The 18-day old seedlings were transplanted in straight row using 2 to 3 seedlings per hill at $20 \mathrm{~cm} \times 20 \mathrm{~cm}$ spacing between hills and rows.

The experimental area was laid out in split-plot arranged in RCBD with three replications. The area of each replication was $385 \mathrm{~m}^{2}$, separated by 0.75 alleyway. Within the alleyways were 0.25 meter irrigation canals, 0.25 meter levees, and 0.25 meter drainage canals, to facilitate the operation and management of the experiment. Each individual subplot had an area of $4 \times 5 \mathrm{~m}$ surrounded by 0.25 meter levees, and 0.25 meter canals between plots to separate each treatment replicate. The treatments were as follows;

\section{Main Plot (Stubble Cutting Height)}

$C_{1}-5 \mathrm{~cm}$ from ground level to base of plant

$\mathrm{C}_{2-}-10 \mathrm{~cm}$ from ground level to base of plant

$\mathrm{C}_{3}-15 \mathrm{~cm}$ from ground level to base of plant

$\mathrm{C}_{3}-20 \mathrm{~cm}$ from ground level to base of plant

\section{Sub-Plot (Fertilizer Application)}

\section{$F_{1-}$ No Fertilizer}

$\mathrm{F}_{2}$ - Soll Application of $60 \mathrm{~kg} \mathrm{~N}, 30 \mathrm{~kg} \mathrm{P}_{2} \mathrm{O}_{5}$ and $30 \mathrm{~kg} \mathrm{~K} \mathrm{~K}_{2} \mathrm{O}(285.71 \mathrm{~g}$ ammonium sulfate, $428.58 \mathrm{~g}$ complete fertilizer) after harvesting period

$\mathrm{F}_{3}$ - Soil Application of $60 \mathrm{~kg} \mathrm{~N}, 30 \mathrm{~kg} \mathrm{P} \mathrm{P}_{2}$ and $30 \mathrm{~kg} \mathrm{~K} 2 \mathrm{O}(285.71 \mathrm{~g}$ ammonium sulfate, $428.58 \mathrm{~g}$ complete fertilizer) after harvesting period $\left(F_{2}\right)+$ foliar application of 8 tablespoons of Super Harvest per 16 liters of water (Company recommendation for rice) 
$F_{4-}$ Foliar Application of 8 tablespoons of Super Harvest fertifizer per 16 liters of water (company recommendation for rice)

Each treatment plot was applied with $285.71 \mathrm{~g}$ ammonium sulfate (21-0-0/20m²) and $428.58 \mathrm{~g}$ complete fertilizer (14-14-14)/20 $\mathrm{m}^{2}$ to meet the soil fertilizer requirement for the main crop. The $60-30-30 \mathrm{~kg} \mathrm{~N}$, $\mathrm{P}_{2} \mathrm{O}_{5}$, and $\mathrm{K}_{2} \mathrm{O} /$ ha rate is based from $\mathrm{ViSCA}$ recommendation for rice.

\section{Cultural Management of Ratoon Crop}

Broadcast application of $285.71 \mathrm{~g}$ ammonium sulfate $(21-0-0)$ and $428.58 \mathrm{~g}$ complete fertilizer was done for those under $F_{1}$ (control) and $F_{4}$ (foliar application of fertilizer) once every two weeks interval after harvesting. The $60-30-30 \mathrm{~kg} \mathrm{~N}, \mathrm{P}_{2} \mathrm{O}_{5}$ and $\mathrm{K}_{2} \mathrm{O}$ recommendation rate was also used.

Super Harvest foliar fertilizer containing $7.97 \% \mathrm{~N}, 3.39 \% \mathrm{P}, 1.14 \% \mathrm{~K}$, $19.20 \mathrm{ppm}$ zinc and other elements like $\mathrm{Ca}, \mathrm{Mg}, \mathrm{Bo}, \mathrm{Fe}, \mathrm{Cl}, \mathrm{Mn}, \mathrm{Mo}$, and $\mathrm{Cu}$, plus growth hormone was sprayed to the foliage of rice (Except those under $F_{1}$ and $F_{2}$ ) at a concentration required for the specific treatments. Foliar application of Super Harvest was done once every two weeks after broadcast application of granule fertilizer $\left(F_{3}\right)$ and after harvest of the main crop $F_{4}$ during the vegetative period until booting stage of the rationed rice.

Harvesting and processing were done when $90 \%$ of the grains in each treatment plot had already ripened. This was performed in the inner rows excluding the border row in every treatment plot. Sharp sickles were used to cut the panicles at their base depending on the cutting treatment designated during the field lay-out on each plot. The sample panicles were threshed after which the grains were sundried for four days and then winnowed. 
Agronomic parameters including the yield and yield components of rice were taken.

\section{RESULTS AND DISCUSSION}

Initial soil analyses showed that the area had a pH of 5.40 , organic matter content of $2.51 \%, \mathrm{P}$ of 0 (trace) ppm and $\mathrm{K}, 22 \mathrm{ppm}$. There was slight increase in $\mathrm{pH}$ and organic matter content after the 2 cropping seasons. Phosphorus was noted to increase after the conduct of the experiment.

Agronomic characteristics of ratoon (Table 1) significantly affected by the treatment were the number of days from cutting to heading and harvesting, plant height, leaf area index and straw yield wherein plant cut at $5 \mathrm{~cm}$ from the base of the plant head earlier resulting to a highly significant difference in the average number of days from cutting to heading and harvesting. Interaction effect of each treatment on plant height showed that plants applied with granular + foliar fertilizer obtained the longest plant height; this was followed by those applied with granular fertilizer only, foliar fertilizer alone, and lastly by the control-no fertilizer. In the case of LAl, a stubble height of $10 \mathrm{~cm}$ produced ratoon with the highest LAl applied with any of the fertilizer treatments, either granular or foliar, or a combination of two (2) treatmients (Figure 1)

For straw yield, on the other hand, result shows that the taller the cutting height of stubbles, the heavier the straw yield of ratoon. The reason for the low straw yield of ratoon from the shortly cut stubbles $(5$ and $10 \mathrm{~cm}$ ) is that there were more dead buds in the nodes closer to the 
ground, thus the bulk of straw yield was reduced. The best fertilizer treatment attributed to the increase in straw yield was the application of granular + foliar fertilizer $\left(F_{3}\right)$.

Table 1. Agronomic characteristics of ratoon rice averaged for two cropping seasons.

\begin{tabular}{llllll}
\hline \hline Treatment & $\begin{array}{l}\text { No. of Days } \\
\text { from cutting } \\
\text { to heading }\end{array}$ & $\begin{array}{l}\text { No. of Days } \\
\text { from cutting } \\
\text { to harvesting }\end{array}$ & $\begin{array}{c}\text { Plant } \\
\text { Height } \\
\text { (cm) }\end{array}$ & $\begin{array}{c}\text { Leaf } \\
\text { Area } \\
\text { index } \\
\text { (LA) }\end{array}$ & $\begin{array}{c}\text { Straw } \\
\text { Yield } \\
\text { (tha) }\end{array}$ \\
\hline
\end{tabular}

Stubble Cutting Height $(\mathrm{cm})$

\begin{tabular}{|c|c|c|c|c|c|}
\hline$C_{1} \cdot 5$ & $29.29 b$ & 70.96 & 85.33 & $3.15 b$ & $9.46 \mathrm{~b}$ \\
\hline$C_{2}-10$ & $30.17 a$ & 71.75 & 85.54 & $3.34 a$ & $9.72 b$ \\
\hline$C_{3}-15$ & $30.50 \mathrm{a}$ & 71.25 & 86.26 & $3.16 \mathrm{~b}$ & $10.79 \mathrm{a}$ \\
\hline$C_{4}-20$ & $29.92 \mathrm{ab}$ & 70.38 & 85.90 & $3.13 \mathrm{~b}$ & $11.04 \mathrm{a}$ \\
\hline F-test & & $\mathrm{ns}$ & ns & $* *$ & \\
\hline
\end{tabular}

\section{Fertilizer Treatment}

\begin{tabular}{|c|c|c|c|c|c|}
\hline $\begin{array}{l}F_{1} \text { - control } \\
\text { (no fertilizer) }\end{array}$ & $29.08 \mathrm{~b}$ & $65.00 \mathrm{c}$ & 73.930 & $2.45 b$ & $9.83 b$ \\
\hline $\begin{array}{l}\mathrm{F}_{2}-\text { Soil appl'n of } \\
\quad 60-30-30 \mathrm{~kg} \mathrm{~N} \mathrm{P}_{2} \mathrm{O}_{5} \text { and }\end{array}$ & $\begin{array}{l}30.17 \mathrm{ab} \\
\mathrm{K}_{2} \mathrm{O}\end{array}$ & $71,29 \mathrm{~b}$ & 89.68ab & $3.53 a$ & $10.45 \mathrm{ab}$ \\
\hline $\begin{array}{l}\mathrm{F}_{3}-\mathrm{F} 2+\text { Foliar of } \\
8 \text { lbsp/16 lit of } \mathrm{H}_{2} \mathrm{O}\end{array}$ & $31.42 \mathrm{a}^{\circ}$ & $76.79 a$ & $35.82 \mathrm{a}$ & $3.48 \mathrm{a}$ & $10.76 \mathrm{a}$ \\
\hline $\begin{array}{l}\mathrm{F}_{4}-\text { Foliar appl'n } \\
\text { of } 8 \mathrm{bsp} . / 16 \text { lit. of } \mathrm{H}_{2} \mathrm{O}\end{array}$ & $29.21 \mathrm{~b}$ & $71.33 b$ & $84.59 b$ & 3.43 & $9.97 a b$ \\
\hline F-test & ** & ** & * & ** & 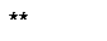 \\
\hline CV\% (a) & 3.00 & 2.00 & 2.54 & 3.41 & 8.00 \\
\hline $\mathrm{CV} \%$ (b) & 3.52 & 1.73 & 1.74 & 5.31 & 6.23 \\
\hline
\end{tabular}




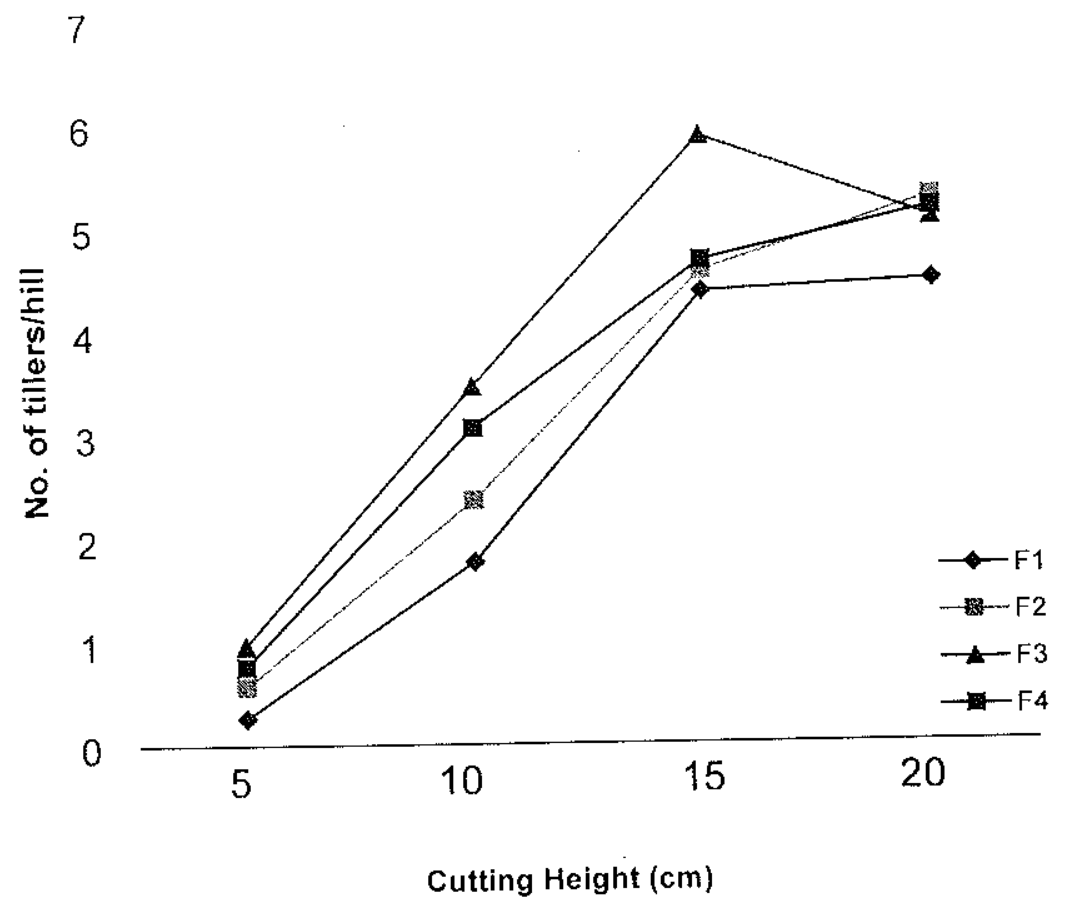

Figure 1. Interaction effect of stubble cutting height and fertilizer treatment on the tillering rate ( $2^{\text {nd }}$ week) of ratoon rice. 
For the yield and yield components, interaction effect between cutting heights and fertilizer treatment were observed in tillering rate during the $2^{\text {nd }}$ and $3^{\text {rd }}$ weeks after harvesting (Table 2). More tillers were exhibited in $15 \mathrm{~cm}$ and $20 \mathrm{~cm}$ cutting, with a fertilizer treatment of granular + foliar application.

Table 2. Yield and yield components of ratoon rice averaged for two cropping seasons.

\begin{tabular}{|c|c|c|c|c|c|c|c|}
\hline Treakment & $\begin{array}{l}\text { Number of } \\
\text { productive } \\
\text { Tillers/hill }\end{array}$ & $\begin{array}{l}\text { Panicle } \\
\text { Length } \\
\text { (cm) }\end{array}$ & $\begin{array}{c}\text { Panicle } \\
\text { Weight } \\
\text { (gm) }\end{array}$ & $\begin{array}{l}\text { No. of Grains } \\
\text { per panicle }\end{array}$ & $\begin{array}{l}\text { Weight of } \\
1000 \\
\text { grains }\end{array}$ & $\begin{array}{l}\text { Grain } \\
\text { Yield } \\
\text { (tha) }\end{array}$ & $\begin{array}{l}\text { Harvest } \\
\text { Index }\end{array}$ \\
\hline
\end{tabular}

\section{Stubble Cutting Height ( $\mathrm{cm}$ )}

\begin{tabular}{|c|c|c|c|c|c|c|c|}
\hline$C_{1}-5$ & $2.21 \mathrm{c}$ & 18.84 & 3.82 & $78.32 \mathrm{~b}$ & $18.59 \mathrm{c}$ & $0.67 \mathrm{~b}$ & $0.07 d$ \\
\hline$C_{2}-10$ & $3.30 \mathrm{~b}$ & 19.09 & 3.80 & $81.35 \mathrm{~b}$ & $20.91 a b$ & $0.89 b$ & $0.08 \mathrm{c}$ \\
\hline$C_{3}-15$ & $7.23 \mathrm{a}$ & 19.29 & 3.82 & $94,20 \mathrm{a}$ & $21.37 a$ & $1.13 a$ & $0.09 a$ \\
\hline$C_{4}-20$ & $7.40 \mathrm{a}$ & 19.35 & 3.84 & $92.65 a$ & $20.60 \mathrm{~b}$ & $1.09 a$ & $0.09 b$ \\
\hline F. lest & $\star \star$ & ns & ns & & & & \\
\hline
\end{tabular}

\section{Fertilizer Treatment}

\begin{tabular}{|c|c|c|c|c|c|c|c|}
\hline $\begin{array}{l}F_{1} \text { - control } \\
\text { (no fertilizer) }\end{array}$ & $4.09 \mathrm{~b}$ & $18.36 \mathrm{~b}$ & 3.61 & $76.55 \mathrm{c}$ & $18.95 \mathrm{c}$ & $0.79 b$ & $0.07 \mathrm{c}$ \\
\hline $\begin{array}{l}\mathrm{F}_{2} \text { - Soil appl'n } \\
60-30-30 \mathrm{~kg} \\
\mathrm{~N}_{1} \mathrm{P}_{2} \mathrm{O}_{5} \text { and } \\
\mathrm{K}_{2} \mathrm{O}\end{array}$ & $5.29 \mathrm{a}$ & $19.11 \mathrm{ab}$ & 3.88 & $86.12 b$ & $20.37 b$ & $0.94 a b$ & $0.08 \mathrm{bc}$ \\
\hline $\begin{array}{c}\mathrm{F}_{3}-\mathrm{F} 2+\text { Foliar } \\
8 \mathrm{tbsp} / 16 \text { lit } \\
\text { of } \mathrm{H}_{2} \mathrm{O}\end{array}$ & $54.58 \mathrm{a}$ & $19.67 a$ & 3.98 & $95.04 a$ & 21.913 & $1.05 a$ & $0.09 a$ \\
\hline $\begin{array}{c}F_{4}-\text { Foliar appl'n } \\
\text { of } 8 \mathrm{tbsp} / 16 \\
\text { lit. of } \mathrm{H}_{2} \mathrm{O}\end{array}$ & $5.20 \mathrm{a}$ & $19.43 a$ & 3.90 & $88.85 a b$ & $20.24 \mathrm{~b}$ & $0.92 a b$ & $0.08 b$ \\
\hline$F$ - test & ${ }^{\star *}$ & ** & ** & $\star \star \star *$ & ** & ** & ** \\
\hline CV\% (a) & 5.00 & 2.00 & 5.00 & 9.00 & 1.00 & 14.00 & 12.00 \\
\hline $\mathrm{CV} \%(\mathrm{~b})$ & 8.76 & 3.07 & 2.05 & 3.41 & 2.99 & 8.57 & 7.31 \\
\hline
\end{tabular}


Application of fertilizer in basal $\left(F_{2}\right)$ or in foliar $\left(F_{4}\right)$ alone increased tiliering but not as much as that of application of fertilizer treatment of granular + foliar application $\left(F_{3}\right)$ treatment. Application of fertilizer increased tillering, thus producing more productive tillers/hill. Panicle length and panicle weight were not much affected by cutting treatment but significant effects were shown under fertilizer treatment. Interaction effect of treatments on ratoons in terms of panicle weight, number of grains/panicle, weight of 1000 grains, grain yield and harvest index were also noted. The trend in crop performance was more or less the same with other parameters mentioned above. Plants performed better when cut at $15 \mathrm{~cm}$ and $20 \mathrm{~cm}$ and applied with both granular and foliar fertilizer. This treatment $\left(F_{3}\right)$ was followed by application of granular fertilizer alone, and foliar fertilizer alone. Both fertilizer treatments, $F_{2}$ and $F_{4}$, had similar effect. Plants under the control treatment performed the least among other treatments due to lack of microelement needed by plant ( Figure 2).

Cost and return analyses showed that plants cut at 15 and $20 \mathrm{~cm}$ were the most economical giving net returns of $\mathrm{R} 20,434.78$ and P21,315.78, respectively. As to fertilizer treatment, soil application of 60 $30-30 \mathrm{~kg} \mathrm{~N}, \mathrm{P}_{2} \mathrm{O}_{5}$ and $\mathrm{K}_{2} \mathrm{O}$ produced the highest net return of P19,868.56 folowed by the control ( $(219,590.78)$. The decrease of net income for the other two treatments (basal + foliar application of fertilizer $\left(F_{3}\right)$ and foliar alone $\left(F_{4}\right)$ were due to the high cost of materials and labor (Table 3). 


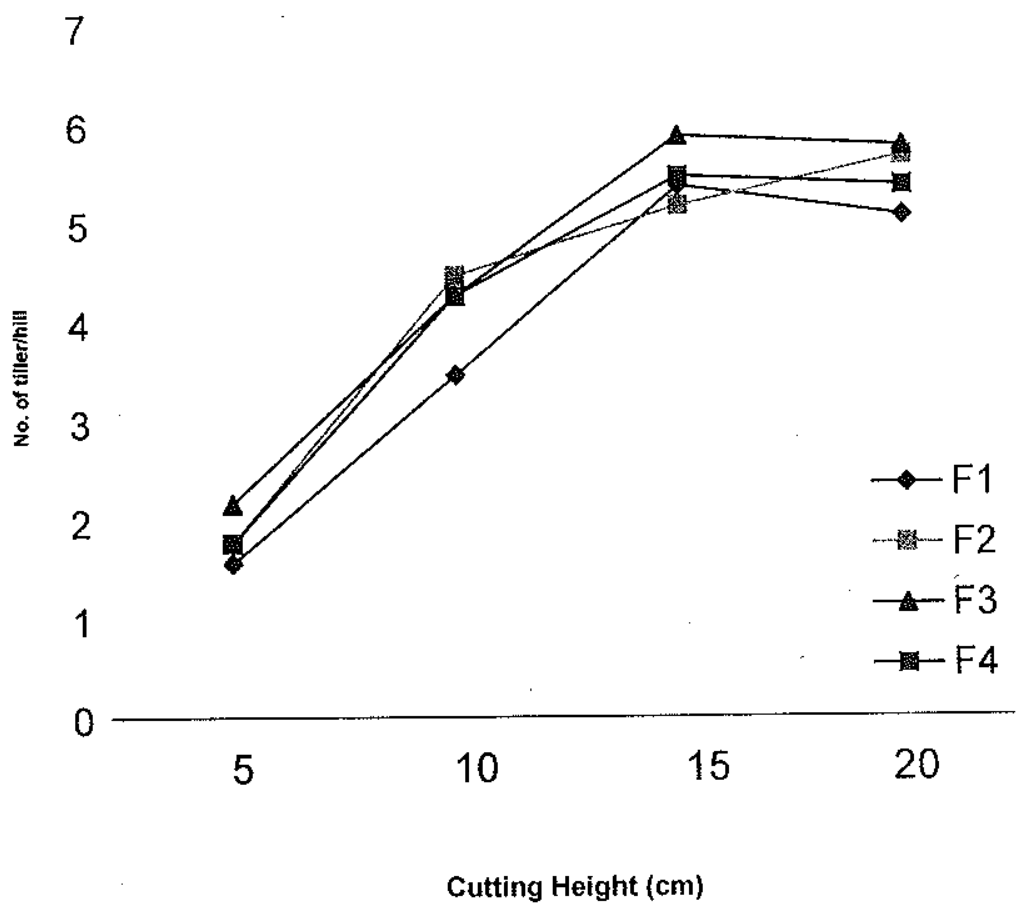

Figure 2. Interaction effect of stubble cutting height and fertilizer treatment on the tillering rate ( $3^{\text {rd }}$ week) of ratoon rice. 
Table 3. Cost and return analysis of lowland rice (main crop + ratoon crop) as affected by stubble cutting height and fertilizer management.

\begin{tabular}{|c|c|c|c|c|c|c|c|}
\hline \multirow[t]{3}{*}{ TREATMENT } & \multirow{2}{*}{\multicolumn{2}{|c|}{$\begin{array}{c}\text { Gross Income (P) } \\
\text { Main Crop + } \\
\text { Ratoon Crop } \\
\text { CROPPING } \\
\end{array}$}} & \multirow[t]{3}{*}{$\begin{array}{l}\text { Total } \\
\text { (Yriha) }\end{array}$} & \multirow{2}{*}{\multicolumn{2}{|c|}{$\begin{array}{c}\text { Gross Expenses (P) } \\
\text { Main Crop + Ratoon } \\
\text { Crop } \\
\text { CROPPING }\end{array}$}} & \multirow[t]{3}{*}{$\begin{array}{c}\text { Total } \\
\text { (Yr/ha) }\end{array}$} & \multirow[t]{3}{*}{$\begin{array}{c}\mathrm{Nel} \\
\text { Income } \\
(\mathrm{P}) \\
(\text { Yr/ha) }\end{array}$} \\
\hline & & & & & & & \\
\hline & 1s! & 2nd & & 1 st & $2 n d$ & & \\
\hline \multicolumn{8}{|c|}{ Cutting Height (cm) } \\
\hline$C_{1}-5$ & 26962.00 & 25993.00 & 52955.00 & 24075.22 & 16069.50 & 40144.72 & 12810.28 \\
\hline $\mathrm{C}_{2-10}$ & 29010.50 & 27021.50 & 56032.00 & 24075.22 & 96069.50 & 40144.72 & 15887.28 \\
\hline$C_{3-15}$ & 30127.00 & 29452.50 & 60579.50 & 24075.22 & 16069.50 & 40144.72 & 20434.78 \\
\hline$C_{4}-20$ & 30744.50 & 29716.00 & 60460.50 & 24075.22 & 16069.50 & 40144.72 & 20315.78 \\
\hline \multicolumn{8}{|c|}{ Fertilizer Treatment } \\
\hline$F_{1}-$ control & 28313.50 & 26662.00 & 54935.50 & 24075.22 & 10069.50 & 35344.72 & $\{9590.78$ \\
\hline $\begin{array}{l}\mathrm{F}_{2} \text { - soil aptin } \\
\mathrm{O} 60-30- \\
30 \mathrm{~kg} \mathrm{~N} \\
\mathrm{P}_{2} \mathrm{O}_{5} \text { and } \\
\mathrm{K}_{2} \mathrm{O}\end{array}$ & 29563.00 & 28356.00 & 57919.00 & 24075.22 & 13975.22 & 38050.44 & 19868.56 \\
\hline $\begin{array}{c}\mathrm{F}_{3}-\mathrm{F}_{2}+\text { foliar } \\
\text { lit of } \mathrm{H}_{2} \mathrm{O}\end{array}$ & 30532.00 & $29 \div 63.50$ & 59695.50 & 24075.22 & 18865.22 & 42940.44 & 1675506 \\
\hline $\begin{array}{l}\mathrm{F}_{4}-\text { foliar } \\
\text { apl'n of } \\
8 \text { tbsp/16 } \\
\text { 能 of } \mathrm{H}_{2} \mathrm{O} \\
\end{array}$ & 29435.00 & 28050.50 & 58485.50 & 24075.22 & 16159.50 & 40234.50 & 17251.00 \\
\hline
\end{tabular}

\section{CONCLUSION AND RECOMMENDATION}

Growth and yield parameters of ratoon rice were significantly affected by cutting height and fertilizer treatment. Among these parameters were the number of days from cutting to heading and harvesting, plant height, $\mathrm{LAl}$, and straw yield.

There is a direct interaction between cutting height and fertilizer treatment as far as tillering rate, panicle weight, number of grains/panicle, weight of 1000 grain, grain yield and harvest index are concerned. 
Cutting height of $15 \mathrm{~cm}$ and $20 \mathrm{~cm}$ produced the highest grain yield/yr/ha with an average of $1.132 \mathrm{t} / \mathrm{ha} / \mathrm{yr}$ and $1.087 \mathrm{t} / \mathrm{ha} / \mathrm{yr}$, respectively. On the other hand, fertilizer treatment using granular + foliar $\left(F_{3}\right)$ obtained the best result with yield of 1,047 tha/yr.

Cost and return analyses revealed that plants cut $15\left(\mathrm{C}_{3}\right)$ and $20 \mathrm{~cm}$ $\left(\mathrm{C}_{4}\right)$ from the ground obtained the highest net income of $\mathrm{P} 20,434.78$ and $\mathrm{F} 20,315.78$, respectively. Basal application of $60-30-30 \mathrm{~kg} \mathrm{~N}, \mathrm{P}_{2} \mathrm{O}_{5}$ and $\mathrm{K}_{2} \mathrm{O}$ produced the highest net return of $\mathrm{R} 19,868.56$.

Since there were significant differences noted on the effect of different cutting treatments of ratoon rice under the same soil and environment condition, it is recommended that both 15 and $20 \mathrm{~cm}$ cutting height be tried for optimum yield of ratoon.

As observed in the cost and return analyses, it is also recommended that basal or soil application of $60-30-30 \mathrm{~kg} \mathrm{~N}, \mathrm{P}_{2} \mathrm{O}_{5}$ and $\mathrm{K}_{2} \mathrm{O}$ be used after harvest to minimize labor cost during fertilizer application.

\section{LITERATURE CITED}

DE DATTA, S.K. and P.C. BERNASOR. 1988. Agronomic principles and practices of rice ratooning. International Rice Research Institute (IRRI), Los. Baños, Laguna, Philippines. pp. 163.

HARDY, B. (ed.). 1998. Focus on hybrid rice. International Rice Research Newsletter (IRRN). 23 (2):2. 


\section{ABOUT THE AUTHOR}

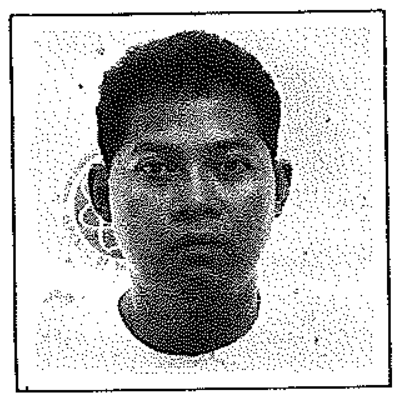

The senior author obtained his Bachelor of Science degree in Agriculture major in Agronomy from the then Visayas State College of Agriculture now Leyte State University. After graduation, he was hired as Science Research Assistant of the National Abaca Research Center for nine (9) years. As a researcher that time, he also pursued his studies leading to Master of Science in Agriculture with major in Agronomy minor in. Education. He transferred to Negros State College of Agriculture (NSCA), Kabankalan City, Negros Occidental as Education Program Specialist (EPS). A year after his appointment as Instructor I, he was promoted to Instructor III and Designated as Director for Research and Development. 